\title{
Regulating oceanic imaginaries: the legal construction of space, identities, relations and epistemological hierarchies within marine spatial planning
}

\author{
Mara Ntona $^{1}$ (D) Mika Schröder $^{1}$ \\ Received: 1 May 2019 / Accepted: 16 January 2020 / Published online: 4 February 2020 \\ (C) The Author(s) 2020
}

\begin{abstract}
A growing body of critical social-scientific scholarship addresses the implications of marine spatial planning for those who depend on the ocean for their livelihood, sustenance, well-being and cultural survival. Of particular concern are planning initiatives that construct marine space in ways that negate or contradict its particular materiality, the latter holding great significance for how different actors relate to the ocean. In response, scholars are turning towards relational conceptualisations of marine space, focusing on the relationships between human and non-human actors, as well as the factors that mediate them. Here, we argue that legal geography, a strand of interdisciplinary research that explores how space, law and society are co-constituted, can make a valuable contribution to this discussion. In taking seriously the connections between the themes law as discourse, law as representation and law as power, legal geography offers a deeper understanding of the subjectivities, narratives and sources of normativity made in/visible by the legal dimensions of planning frameworks. Using the legal-geographical concept of spatial justice as our frame of reference, we posit that the relational materiality of the ocean lends itself to the socio-legal construction of marine spaces as 'commons', i.e. as pluralist spaces where different knowledges and ways of being coexist and intermingle, and where well-being is perceived in composite, socio-natural terms. This allows us to problematise marine spatial planning, along with its normative, regulatory and institutional underpinnings, as a vehicle for the enclosure of not only marine spaces but also spaces of decision-making.
\end{abstract}

Keywords Public participation $\cdot$ Spatial justice $\cdot$ Legal geography $\cdot$ Enclosure $\cdot$ Ecosystem approach $\cdot$ Blue growth

\section{Introduction}

The last few years have seen a growing body of critical social-scientific scholarship addressing the implications of marine spatial planning (MSP) for those who depend on the ocean for their livelihood, sustenance, well-being and cultural survival. These studies lay bare the values, causeand-effect relationships and persisting uncertainties that capitalist-industrial framings of the ocean tend to disregard or downplay (Winder and Le Heron 2017). They also demonstrate that the governance of the marine commons is becoming subject to an increasingly managerial, technocratic approach with far-reaching repercussions for

\section{Mara Ntona}

maria.ntona@strath.ac.uk

1 University of Strathclyde, Law School and SCELG, Glasgow, UK coastal communities (Murray et al. 2010). Each in its own way, these studies grapple with questions of power and equity, drawing attention to the hidden, overlooked or unforeseen trade-offs involved in MSP processes (see, indicatively, Flannery and Ellis 2016). Of particular concern are planning initiatives which construct marine space in such a way as to negate or contradict its particular materiality, the latter holding great significance for how different actors relate to the ocean (Lavau 2013). In response, the MSP community is progressively turning towards a relational conceptualisation of marine space, which places the focus on the relationships between human and non-human actors, as well as the factors that mediate them (Boucquey et al. 2016: 2).

The role of law in this respect has remained largely unexplored. This is despite the lively debate taking place among critical geographers and critical socio-legal scholars with regard to law's "anti-geographical tendencies"; that is, law's habitual disregard for the physical, the spatial and the cultural 
(Bennett and Layard 2015). An important insight that can be gleaned from this debate is that, by promoting abstracted, reductionist understandings of space, law discounts local distinctiveness, thus disenfranchising vulnerable groups. This concern lies at the heart of legal geography, a strand of interdisciplinary research that explores the diverse ways in which space, law and society are co-constituted (Delaney 2010). In taking seriously the connections between the themes law as discourse, law as representation and law as power, legal geography brings forth new questions vis-à-vis law's involvement in the production, maintenance and transformation of space. It invites us to interrogate the role of law as a medium for the articulation of normative discourses and their forceful projection upon reality. It quickly becomes apparent that the neoliberal, modernist narratives that MSP is predicated upon give rise to positivist epistemologies, which exclude certain actors, along with their knowledges, interests and perspectives, from spaces of deliberation and decision-making. Legal geography also invites us to question how the regulatory tools (e.g. area-based conservation measures), representational devices (e.g. maps) and information management technologies (e.g. geographic information systems) associated with MSP work together to "gentrify" marine spaces, constructing them in ways that reflect the hierarchy of values and the differentiated rights of access that have come to characterise terrestrial landscapes (Ryan 2015: 570).

This article seeks to demonstrate that a greater engagement with legal-geographical research can provide a deeper understanding of the subjectivities, narratives and sources of normativity that MSP frameworks make in/visible. It invites legal scholars and practitioners to familiarise themselves with the ocean's dimensionality, fluidity and transience and to contemplate what these material qualities mean for efforts to 'regulate' and 'manage' human-ocean interactions. The article's core thesis is that the unruly, relational materiality of water worlds readily lends itself to their socio-legal construction as 'commons', i.e. as pluralist spaces where different forms of knowledge and ways of being coexist and intermingle (Hardt and Negri 2009; Lavau 2013) and where well-being is perceived in composite, socio-natural terms (Castree and MacMillan 2001). This viewpoint makes it possible to problematise MSP, as well as its normative, regulatory and institutional underpinnings, as a vehicle for the enclosure of the marine commons.

Before we delve into this discussion, it is worth clarifying that the paper illustrates its arguments through references to European and international legal texts of relevance to MSP. In setting the tone for the practice of 28 states vis-à-vis MSP, European Union (EU) law suggests itself as an important field in which to research the intersection between the normative, the regulatory and the spatial. International biodiversity law, on the other hand, is an emerging source of alternative approaches to the incorporation of socio-cultural considerations into environmental decision-making processes. In neither case does our engagement with legal instruments amount to a comprehensive doctrinal analysis. Our purpose is simply to show that what may appear to be a rather theoretical approach to matters of spatial justice within MSP actually has very tangible applications in relevant legal practice.

\section{Spaces of Law and Law in Spaces}

In contemplating how the normative-discursive and regulatory-administrative dimensions of MSP are implicated in the construction, perpetuation, transformation and dismantling of spatiotemporal and social boundaries, we draw on the 'relational turn' within geography, law and other socialscientific disciplines. We do so with a view to bringing together insights from an emerging body of critical MSP and sociolegal scholarship that uses relational thinking to unpack "the ways in which entities, thought of as processes rather than existents, become entwined" (Watts 2014: 1). Critical MSP scholars are adopting a relational perspective to explore the interactions through which marine space acquires its shape and meaning, and to illustrate the tension between the ocean's seemingly anarchic materiality and the methods used to 'manage' and 'govern' it (see, for instance, Jay 2018). For their part, critical and socio-legal scholars, and in particular scholars active in the field of legal geography, are exploring how law both reflects and constitutes social perceptions and physical manifestations of space, serving to 'naturalise' particular socio-material realities (see, for instance, Steinberg 2001). The two discourses are equally preoccupied with issues of power and equity, and the ways in which actors become marginalised within decision-making processes. In combining these two strands of relational inquiry, we seek to determine how, in the absence of a meaningful engagement with the ocean's spatiality and materiality, MSP's normative, regulatory and institutional underpinnings may contribute to the enclosure of spaces constructed-or amenable to being constructed - as commons.

Relational thinking gives rise to an "open-ended, mobile, networked, and actor-centred" notion of space (Jones 2009: 487), which acknowledges the "interconnections and co-constituencies" between the material and the immaterial, between the human and the non-human and between nature and culture (Pierce et al. 2011: 67). Spatiality thus becomes viewed as an open plane of possibility, wherein the values, knowledge systems and embedded practices of heterogeneous actors are perpetually clashing, melding and being transfigured, imbuing space with political meaning (Lefebvre 1991). It also becomes evident that space holds an inseparable temporal aspect: it is "always under construction ... never finished, never closed" - in other words, part of a continuum of activity (Massey 2005: 9; Davies 2017a: 441-2). This is precisely 
the quality that Massey sought to convey by referring to space as the realm of "radical contemporaneity" and to places as "spatio-temporal [events]"; that is, as temporary crystallisations of the interplay between different placemaking narratives and practices and, by extension, as snapshots of the underlying power dynamics (Massey 2005: 195, 130-1).

Within critical MSP scholarship, relational thinking is being used as a conceptual and methodological tool for analysing the discourses and practices involved in the sociomaterial production of marine space (Jay 2012; Kidd and Shaw 2013; Boucquey et al. 2016; Fairbanks et al. 2018; Jay 2018; Barry and Gambino 2019). In this context, relational thinking highlights how the very materiality of the ocean appears to defy the confines of traditional modernist modes of planning, which are based on a view of 'objects' (e.g. built structures, landscapes, communities) as "bounded entities, fitting together in mosaic-type patterns" (Jay 2012: 83). Such a conceptualisation of spatiality sits uncomfortably with the four-dimensional structure of the ocean, which allows different uses to be made of the water surface, the water column, the seabed and the sub-seabed, either simultaneously or sequentially (Duck 2012; Gilbert et al. 2015). It is also difficult to reconcile with the inherently mobile nature of the ocean: its currents, substances, sediments and living inhabitants. This dissonance compels us to take a view of "marine space-being-planned" not as a "static and momentary image", but as a moving and continually changing entity - in other words, as a "lively space" (Jay 2018: 450-1, 462).

Armed with this new spatial imagination, social scientists have begun to paint a richer picture of the interactionsbetween natural processes, organisms, social actors, technology, science and law-through which marine space is produced (Bear 2012). Their efforts are in line with conceptualisations of marine spaces as 'commons' and as 'social-ecological systems', both of which understand the spatiality of the oceans as being inherently relational. Indeed, each common can be said to encompass an intricate constellation of relationships between resources, their physical-material domain and their users (Giordano 2003). These relationships are mutually constitutive: on the one hand, the institutions that govern resource use unequivocally shape spatial structures and dynamics; on the other hand, the socioeconomic and environmental features of an area have a direct bearing on the opportunities available for collective action (Moss 2014: 458). As for social-ecological systems, these are understood to be complex adaptive systems in which the 'social' and the 'ecological' are entwined in intricate patterns of reciprocal feedback (Berkes 2012: 468). The two subsystems operate as "a coupled, interdependent and co-evolutionary" whole (ibid), and any attempt to delineate between them is perceived as artificial and arbitrary (Berkes et al. 2002). A key point to make here, and one that will be discussed in greater detail below, is that, by highlighting the inextricable link between the human and the natural worlds, both the discourse on the commons and that on social-ecological systems point to a composite understanding of well-being, cognizant of the reciprocity between social and ecological integrity.

These insights resonate with how critical and socio-legal scholars have been using relational thinking to situate law within its social and spatiotemporal context, and draw attention to the diverse spaces, forms of subjectivity and discourses implicated in the emergence and formalisation of legal norms (Davies 2017b: 129). The preoccupation here is with asserting law's materiality and plurality. In regarding law as a material phenomenon, scholars are assigning theoretical significance to the physical world in all its manifestations, from human and non-human life to inorganic matter. In regarding it as plural, they are affirming the existence of diverse epistemological and ontological traditions, diverse knowledge holders within such traditions and "endlessly dynamic connections of 'matter and meaning"' (ibid: ix). These two viewpoints are intertwined: viewing all fields of social and material realities as connected necessarily means recognising the diverse types and genres of law at play. Applying this observation to the present context, one could say that to accept marine spacebeing-planned as 'lively' and materially diverse is also to assert it as legally plural.

Thus, relational thinking serves to "demystify" positivist assumptions about law's neutrality and its statist and formalist foundations (Davies 1996: 2). It subverts the common perception of law as a self-contained and self-sustaining set of principles and values deriving from legal texts and judicial decisions, drawn on by scholars and practitioners in seeking order, rationality and theoretical cohesion (McConville and Hong Chui 2007: 1). This has implications for legal studies, revealing the limitations of traditional approaches grounded in portrayals of law as being 'deaf' to material, physical, spatial and cultural influences (Holder and Harrison 2003: 3). Regarding law as an inherently societal phenomenon, complex and alive in its forms and structures, and in the ways that it is created, used and interacts with other normative structures (e.g. scalar, sectoral and institutional), critical legal scholarship (drawing on realism, critical feminist studies, postcolonial studies, critical race theory and queer studies) illustrates the deeply political and value-laden nature of legal interpretation and practice (Davies 2017a: 32-6). Ultimately, it becomes clear that any one hegemonic approach to conceiving and studying law would be incomplete in telling us what it is or what it does. Simply put, law can, indeed must, be perceived from a multitude of perspectives (ibid).

It is precisely this problematique that triggered the emergence of legal geography as a distinct interdisciplinary field of research. In taking seriously and in exploring the connections between the themes law as discourse, law as representation and law as power, legal geography brings forth new 
perspectives on the situatedness of legal knowledge and practice within social and political life (Blomley et al. 2001: xvii). Its core message is that the relationship between law and space is one of co-production. One of the foremost figures within legal-geographic scholarship, David Delaney (2003a), illustrates this through his categories 'space-in-law' and 'law-in-space'. 'Space-in-law' addresses the ways in which spatial metaphors are used to conceptualise law and legality. It places particular focus on how spatial metaphors become implicated in the elaboration and development of law and legal concepts, and the impact that this has on peoples' lived experiences (consider actors described as living 'inside' or 'outside' the law).

'Law-in-space', on the other hand, refers to the ways in which law is embedded in, and emerges from, the spaces around us. When law is seen through a spatial lens, its materiality becomes clear: planning restrictions, environmental regulations, internal and external borders and different types of property rights (private, common, public, open-access) are all complicit in creating and defining spaces and the relationships therein. But law is not the sole force at play. Rather, spaces are created and defined through the interaction between different normative systems. Crucially, in naming, measuring, categorising and organising space, each system relies on its own particular epistemological and ontological underpinnings. Moreover, each system has a distinct approach to distributing and 'managing' the power struggles at play within different decision-making processes, as well as to dividing up physical space and resources. It follows that each normative system plays a unique part in facilitating broader societal processes of capital production and consumption.

Similar points are raised by Philippopoulos-Mihalopoulos (2015) in his work on spatial justice, which provides a deep reflection on the way that law, space and time interact so as to make in/visible, within a given setting (the 'lawscape'), certain narratives, power structures, knowledges, and legal and social hierarchies. Therefore, law and space can be produced and used in ways that silence or restrict the voices, contributions and perspectives of certain actors while promoting those of others-what Philippopoulos-Mihalopoulos describes as the 'tilted plane' (ibid: 192).

In highlighting the ways in which law and space are coproduced through legal and spatial representation - including through metaphors and imagery_legal geography provides a framework for exploring the naturalisation of uneven power relations through un/seen meaning-making processes taking place within particular spaces. Property law is a case in point. Rather than studying the impact of property rights on the balance of powers between pre-constituted social subjects, legal geographers are engaging in a deeper exploration of how these legal structures and their associated institutions are re/producing the very forms of social agency and the relationality ascribed to humans, non-human persons and 'things', from a historical as well as present perspective (Whatmore 2003: 211). What this exploration reveals is that, in prescribing what qualifies as a property object and who may be regarded as a property right holder, property law profoundly affects one's positionality within space. The same critique can be made of environmental law. Regarding environmental law through a legal-geographical lens exposes the role of the relevant rules and regulations in formalising patterns of 'acceptable' engagement with one's spatial surroundings (Delaney 2003b: 199). Conservation laws, for example, govern spaces and people by erecting borders around features of the natural and cultural environment, assigning particular value to these in accordance with attitudes in science, politics and public opinion. Here, too, law produces categorisations and groups in reflection of supposed societal truths, directing the movement of bodies by assigning categorical identities that work to de/legitimise one's existence within a given space. In sum, we can say that, in determining 'acceptable' and sometimes 'necessary' behaviour, law has the ability to place people 'outside' its protective ambit, thus justifying their persecution and exclusion from society.

Viewed together, the two lines of relational inquiry summarised above, namely the effort to develop a relational ontology and epistemology of marine space and the effort to flesh out the complex interrelationship between space, society and law, are two sides of the same coin. In bringing them together, we seek to use their common loci to address issues of spatial justice within MSP. In particular, we aim to highlight the need to engage with a law that embraces the "energetic materiality" (Bear 2012: 22) and "non-linear temporality" of marine space (Steinberg and Peters 2015: 260) and is receptive of the ways in which these affect oceanic relations. This requires an approach to ocean law and governance that is "horizontal, networked, ecological, and connective" as opposed to vertical, hierarchical and conducive to inequitable forms of enclosure (Davies 2017b: 129). It also calls for a greater awareness of law's embeddedness within societal power structures, and its role in their hegemonic preservation or counter-hegemonic subversion.

Critically, if both marine space and law can and should be regarded as contested arenas, it is hardly tenable to continue framing MSP - a process that is as much politico-normative as it is techno-scientific - in "asocial and apolitical" terms (Flannery et al. 2019: 202). Rather, the MSP community must grapple with planning's capacity to either further entrench or radically uproot existing power dynamics between actors and knowledge systems. One way to broach this problem is by inquiring how MSP promotes or disrupts processes of commoning and enclosure. Owing to their inherent relationality and their amenability to being construed in both spatial and legal terms, these two notions provide a suitable starting point for bringing MSP scholarship into dialogue with the legal-geographical research agenda. From this perspective, 
the commons are best conceptualised as products of placemaking processes whereby communities shape themselves and their surroundings into socio-material bodies through collective institutions, shared territorial practices and discourses (Sevilla-Buitrago 2015: 1003). Enclosure, on the other hand, can be broadly understood as a territorial practice that leads to the erosion and seizure of the commons through the "measurement, allocation, design and legal regulation of space" (ibid: 1005). By virtue of its capacity to shift the balance between "individual and society, subjective and objective, between public and private", the legal sphere is "a privileged domain" in which to interrogate commoning and enclosure (Hardt and Negri 2005: 202). It is through this lens that we examine how the normative, regulatory and institutional dimensions of MSP may transform the materialities, spatialities and subjectivities of the marine commons in ways conducive to enclosure.

These observations can serve as a basis for formulating a relational critique of enclosure within MSP law and practice: in interfering with the capacity of different actors to access, use and manage marine spaces, legal norms may thwart the possibility of using existing - or cultivating new - forms of collectivity to achieve more sustainable and equitable ends (Jeffrey and Vasudevan 2012: 1249). Put more succinctly, the suppression of rights to the marine commons holds the potential to compromise socio-natural well-being (Bennett et al. 2015: 62; Boucquey et al. 2016). In this connection, Murray et al. (2010) have argued that "creeping enclosure", made up of multiple, mutually reinforcing regulatory events and processes, plays a role in creating and reducing opportunities for learning and knowledge-led feedback response in social-ecological systems. It is at the 'coupling space' that scientific, traditional ecological and experience-based knowledge is produced, as human actors respond to information and experiences flowing between the 'environment' and 'society' (ibid: 381). By creating and reinforcing a divide between 'social' and 'natural' worlds, enclosure undermines the prospects for individual and collective learning and adaptation, thus contributing to reduced social memory, social capital and organisational and institutional flexibility. The following section considers the various ways in which law contributes to this phenomenon.

\section{Regulating on oceanic imaginaries: the legal construction of space, identities, relations and epistemological hierarchies within marine spaces}

This section aims to bring to the fore the ways in which law is implicated in the definition, signification and ordering of marine spaces. It highlights the functions performed by law vis-à-vis the prescription of identities and roles, and the promotion of particular oceanic imaginaries; that is, epistemological and ontological constellations that suggest a particular way of visualising, knowing and relating to ocean spaces. What we wish to demonstrate is that law has the capacity to make visible and prioritise the interests and perspectives of particular actors at the expense of others, thus contributing to the 'tilted plane' between bodies. In grounding our analysis in a spatial justice concept that interrogates how law creates and fills physical and conceptual space, ${ }^{1}$ we also seek to take a closer look at how legal discourse and practice may thwart the "radical potential" of MSP (Flannery et al. 2019). We begin by introducing the debates bringing into question the notion of MSP as a democratic decision-making process that provides an equal balance between economic, ecological and social concerns pertaining to the ocean. The insights gleaned from these debates, along with the relational critique of enclosure introduced above, allow us to argue that the oceanic imaginaries promoted by MSP's normative, regulatory and institutional underpinnings serve to perpetuate systemic power imbalances among actors.

\section{Powers at sea: shades of access and exclusion in MSP processes}

MSP is often portrayed as being grounded in participatory and pluralist ideals, with Ehler and Douvere describing it as a "public process for analysing and allocating the spatiotemporal distribution of human activities in marine areas for the achievement of politically-defined ecological, economic, and social objectives" (2009: 18, emphasis added). While some welcome it as a progressive process that enables integrated and democratic decisionmaking in relation to ocean governance (Pomeroy and Douvere 2008), others adopt a more cautious perspective. A key critique relates to the reluctance of MSP practitioners to address systemic power asymmetries between actors and knowledge systems, with many arguing for greater engagement with the social sciences in order to grapple with the social, political and cultural dimensions of the planning process (Ritchie and Ellis 2010; Boucquey et al. 2016; Smith and Jentoft 2017; Smith 2018; Flannery et al. 2019).

The consequences of lasting power imbalances within MSP processes are manifold, leading to both active and passive exclusions of different actors. Here, 'active exclusion' refers to the physical absence of groups and individuals from decision-making spaces, whether due to not being invited, not being able to participate or deciding not to participate (see, indicatively, Flannery et al. 2018). 'Passive exclusion', on the other hand, refers to

\footnotetext{
${ }^{1}$ The idea of 'creating' and 'filling' is inspired by Smith (2015).
} 
instances in which participation is tokenistic in the sense that actors are present, but their views and perspectives are not meaningfully incorporated into the discussion and, hence, do not filter into decision-making. For instance, paternalistic approaches to planning that treat local groups as passive beneficiaries undermine local agency within decision-making spaces (Mancisidor 2015), as do formulaic and static structures that are ill-equipped to meaningfully address social concerns and changes (Armitage et al. 2009). A key issue regarding passive exclusion is the outward legitimising effect this has on a decisionmaking process, making it appear democratic and inclusive. Indeed, without critical reflection on what counts as genuine and inclusive participation, this easily becomes a box-ticking exercise that powerful groups can employ to define and limit roles and processes in ways that make outcomes acceptable to them (Gray and Hatchard 2008; Flannery et al. 2019). The popular perception of MSP as a democratic decision-making mechanism in relation to ocean governance must therefore be questioned, especially if the consequence is the outward legitimisation of decisions made to favour and benefit certain actors while others remain on the periphery.

While literature exists exploring the processes of participation within marine governance (see, for instance, Gray and Hatchard 2008; St. Martin and Hall-Arber 2008; Flannery and Ó Cinnéide 2012a, 2012b, 2012c; Flannery et al. 2018; Maguire et al. 2012; Kraan et al. 2014), there is limited scholarship addressing questions relating to who should be involved in these processes, including who qualifies as a 'stakeholder' and whether there should be a distinct recognition of 'local' stakeholders. While any definition naturally needs to be flexible in order to reflect and accommodate local particularities, legal provisions tend to be worded in non-committal terms that do little to ensure diversity and the inclusion of actors traditionally left at the margins of decision-making processes. ${ }^{2}$ Within MSP, the term 'stakeholder' is steeped in managerial terminology and practice and has evolved into a concept so broad that practically anyone can fall under it (Pomeroy and Douvere 2008).

This pattern echoes a wider trend discernible in international environmental law, including international biodiversity law. For instance, although the Convention on Biological Diversity $(\mathrm{CBD})^{3}$ is one of the more progressive international instruments in terms of providing and facilitating participation by

\footnotetext{
$\overline{2}$ Indeed, article 9 of the EU MSP Directive requires member states to inform "all interested parties" and to consult the "relevant stakeholders and authorities, and the public concerned" at an early stage in the development of marine spatial plans: Directive 2014/89/EU of the European Parliament and of the Council of 23 July 2014 establishing a framework for maritime spatial planning, 2014 O.J. L 257 (hereinafter the MSP Directive). Without further clarity, such broad provisions fail to attribute participatory rights to particular groups. ${ }^{3}$ Convention on Biological Diversity, 5 June 1992. In force 29 December 1993. 1760 U.N.T.S. 79 (hereinafter the CBD).
}

local actors at its negotiations, there is significant conflation between 'stakeholders', effectively resulting in large-scale corporations and global non-governmental organisations being grouped under the same banner as indigenous peoples, local communities, women and youth. ${ }^{4}$ Such an approach ignores the systemic power imbalances that exist within these decision-making spaces, such as differences in access to funding, training in specialised processes, not to mention navigating pre-existing partnerships and alliances. What is more, it does not guarantee the equal recognition of diverse perspectives and knowledges within ensuing discussions (further discussed below). Crucially, this reminds us to be mindful that, even though the recognition as a stakeholder is a key means of gaining access to decision-making spaces, it certainly does not guarantee equal access to relevant processes. Indeed, within MSP specifically, scholars have argued that it is not enough to place new actors in new governance positions, as we must remain attentive to their manoeuvrability within planning processes (Smith 2015). This pertains to the roles they are prescribed, and the respect and recognition awarded to them, their knowledges and worldviews. The remainder of this article will explore these questions by looking at the normative and regulatory inscriptions of power asymmetries, as well as the epistemological and ontological hierarchies that contribute to the enclosure of marine space.

\section{Techno-scientific and legal positivism, and the struggle for epistemic recognition under MSP}

The first feature of MSP frameworks that we draw attention to is the emphasis placed on scientific and managerialtechnological rationality. MSP is often portrayed as a management tool that is uniquely capable of preventing conflicts, facilitating trade-offs and streamlining policy implementation, thus "[fostering] a more rational and wise use of limited ocean space" (Young 2015: 157). Equally characteristic of both growth- and environment-oriented approaches to MSP, this

\footnotetext{
${ }^{4}$ These sentiments were confirmed during one of the authors' fieldwork at the 14th Conference of the Parties to the CBD in November 2018, exploring the meaning and practice of 'local' stakeholder participation at the negotiations. That being said, it should be noted that, notwithstanding the uncertainties surrounding participatory processes under the CBD and the ways in which these address power imbalances, some soft law instruments elaborated under the Convention are recognised by indigenous representatives as incorporating key concerns, for instance related to impact assessments adopting holistic methodologies that account for indigenous and local worldviews, having decision-making processes incorporate local customs in a culturally sensitive manner, recognising the importance of traditional knowledge in biodiversity conservation and ensuring protection of customary laws and practices (see, for instance, the Akwé:Kon Guidelines (CBD COP7 Decision VII/162004); Tkarihwaié:ri Code (CBD COP10 Decision X/422010); Mo'otz Kuxtal Voluntary Guidelines (CBD COP13 Decision XIII/182016); the Rutzolijirisaxik Voluntary Guidelines (CBD COP14 Decision XIV/122018)). Still, this needs to be read in light of criticisms levelled against the CBD's grounding in neoliberal logic that remains underpinned by hegemonic normative hierarchies. See, for instance, Adger et al. (2002) and Vermeylen (2013).
} 
preoccupation with rationality finds expression in legal provisions calling for environmental impact assessment and the use of 'best available data'. ${ }^{5}$ It is also reflected in the common association between MSP and the ecosystem approach. The EU Maritime Spatial Planning Directive, for instance, states that ecosystem-based planning can help ensure that pressures from anthropogenic sources are kept within levels compatible with the achievement of good environmental status. ${ }^{6}$ In turn, the determination of what qualifies as 'good environmental status' is based on a set of qualitative descriptors laid out in EU marine environmental legislation. ${ }^{7}$ These concern the structure, functions and processes of marine ecosystems, together with the associated physiographic, geographic, geological and climatic factors, as well as the relevant physical, acoustic and chemical conditions. ${ }^{8}$ This example lends credence to the claim that, although public participation is widely regarded as a criterion for its implementation (Santos et al. 2014), the ecosystem approach has ultimately developed into a process in which natural science data serves as the primary basis for identifying management needs and setting goals, objectives and thresholds.

On the other hand, the widespread depiction of scientific knowledge as neutral, objective and rational has the effect of obscuring the complexities, cultural contestations and power asymmetries underlying the processes involved in its production (St. Martin and Hall-Arber 2008; Ritchie and Ellis 2010; Knol 2013; Tafon 2018). This observation holds particular relevance in the present context. In light of the discourse on social-ecological systems, it is becoming increasingly clear that engaging across knowledges - particularly knowledges that are spatially grounded, contextual and experiential-is a vital requirement for understanding social-ecological interactivity across multiple spatiotemporal scales. These knowledges tend to be embedded in culturally constructed subjectivities, social networks and practices of use and stewardship that reflect shared views on sustainability and equity (Olson 2010). Persistently grounded in scientific and managerialtechnological epistemologies and ontologies (Agardy et al. 2011; Borja et al. 2016), the implementation of the ecosystem approach relegates such knowledge to the status of anecdotal information, thus giving rise to knowledge hierarchies that detract attention from the manifold social, cultural and spiritual connections between people and the ocean (Tafon 2018; Flannery et al. 2018). Drawing on Foucault, Tafon characteristically argues that the ecosystem approach functions as a “discursive gatekeeping" apparatus (2018: 265), allowing

\footnotetext{
${ }_{5}^{5}$ See, for instance, EU MSP Directive, preambular paragraphs 18 and 23, and article 10.

${ }^{6}$ EU MSP Directive, preambular paragraph 14.

${ }^{7}$ Directive 2008/56/EC of the European Parliament and of the Council of 17 June 2008 establishing a framework for community action in the field of marine environmental policy, 2008 O.J. L 164 (hereinafter the MSFD).

${ }^{8}$ MSFD, Annex I.
}

knowledge/power to be wielded in ways that effectively make possible the 'othering' and the 'marginalisation' of nonscientific knowledge systems and their users. The resulting governance strategies allocate, monitor, sanction, enforce and adjudicate in ways that disempower human subjects and undermine their agency (Agrawal 2003: 258).

These concerns lie at the heart of recent scholarship on two interlinked MSP practices: the use of geographic information systems (GIS) and mapping. As the MSP community has become better-versed in the ecosystem approach, terms such as 'ecosystem', 'species', 'habitat' and 'population' have become part of its vernacular, shaping the performance of data collection and inscription (Boucquey et al. 2019: 6). The relevant practices are also affected by the focus placed on data pertaining to maritime activities that pertain to strategic 'Blue Growth' objectives. GIS are a case in point. These technologies perform a key role in MSP processes, providing planners with foundational data, analyses and visual representations of the space to be regulated (Ryan 2015: 579). Nonetheless, commentators have suggested that the geospatial databases where this information is hosted are not technologically or socially neutral, nor are they objective (Olson 2010: 294). To the contrary, these are value-laden instruments that hold the power to "make new worlds, with particular ocean objects, boundaries, patterns, understandings, perceptions, and practices" (Boucquey et al. 2019: 10). In so doing, they further embed existing power dynamics and shift balances in ways that will prove difficult to reverse in the future, with current trends suggesting the tipping of scales against the socio-cultural dimensions of MSP.

In this connection, attention must be drawn to the realityshaping capacity of the representational devices employed in MSP processes (Smith 2015). Mapping is perhaps the most prominent example, being regularly drawn on as a tool for understanding and visualising marine space (and in this sense, contributing to the demarcation of access rights/restrictions). Yet, insights from critical cartography have illustrated how mapping processes are "performative, participatory and political", reminding us that maps produce as well as represent lived reality (Campton 2009: 840). Viewed through this lens, mapping is revealed as a process that requires simplification of features and processes, ultimately granting only a static, partial and distorted depiction of complex seascapes (Robbins 2003); one that fails to account for the inherently fluid nature of water worlds (Anderson and Peters 2014). Maps also fail to capture the intricacies of socialecological interactions and relations, particularly in terms of the multifaceted cultural ties that have developed between human communities and marine spaces over time (St. Martin and Hall-Arber 2008; Boucquey et al. 2019).

Within MSP, mapping exercises are often driven by actors with an interest in the development of sectoral maritime activities (e.g. seabed mining, marine renewable energy, tourism, 
aquaculture). This leads MSP processes to rely on "proprietary", capital-intensive mapping practices, which approach knowledge not as a good to be co-produced and shared, but as capital to be channelled towards neoliberal intentionalities (Olson 2010: 299). In view of these shortcomings, it appears necessary to interrogate the use of cartographic evidence in combination with legal concepts and principles as a basis for making technocratic, purportedly rational decisions regarding the spatiotemporal distribution of human activities in marine areas.

From a historical and politico-legal perspective, mapping has been used as a tool for enclosing spaces and rendering them amenable to the exercise of 'control'. For instance, mapping has been drawn on to expand imperial boundaries, demarcating land as 'empty' and therefore free for the taking, or as a way of establishing exclusive (sovereign) economic rights over marine space. In all these cases, law is implicated. Early international and domestic law was drawn on to justify the 'civilising' efforts of the Western empires in their colonial expansion (Miller 2011), the legal principle of terra nullius was effectively drawn on by the Australian government and its subjects in their taking of territories which had previously been inhabited by Aboriginal peoples (Banner 2005; Watson 2014) and the 1982 United Nations Convention on the Law of the Sea (UNCLOS) establishes a regime of sovereign rights to marine spaces, which grants coastal states exclusive economic rights to marine resources within 200 nautical miles from the coast. ${ }^{9}$ For a more modern take on the interplay between law and mapping, we may turn to marine cadastral GIS, which form an increasingly significant component of MSP's informational infrastructure. These serve as a comprehensive and permanent inventory of the different types of 'legallyrecognised' rights attached to marine space, including state rights (e.g. rights granted under international law), public rights (e.g. rights of navigation), community rights (e.g. small-scale fishing communities' tenure rights) and private rights (e.g. leases, easements or rights-of-way granted to offshore energy developers). Crucially, marine cadastres provide an authoritative delimitation of the documented rights' spatial scope, employing maps and other visual aids to situate them in relation to maritime zones and boundaries, area-based management measures and a wide array of natural and artificial features (Ehler and Douvere 2009: 61).

The latter example offers further illustration of how law's representational tools can be used to enclose marine space in ways that sit uncomfortably with the ocean's material realities (the ebbs and flows of its tides and swells, the forces of its currents, the movement of species), not to mention the realities facing coastal communities. For instance, the spatiotemporal

\footnotetext{
${ }^{9}$ United Nations Convention on the Law of the Sea, 10 December 1982. In force 16 November 1994. 1836 U.N.T.S. 3 (hereinafter UNCLOS). See articles 55 et seq.
}

scope of fishing regulations neglects impacts wrought by weather patterns, fluctuating oil prices and changes in fish populations due to pressure from non-fishery uses (Smith 2012). Furthermore, cultural ties to the ocean have proven difficult to conceptualise, measure and map, which has served as an excuse for them being left out of studies and impact assessments altogether (Kobryn et al. 2018). This means that we hold an impoverished understanding of how different regulatory measures may impact cultural values and the communities that hold them. It also means that, given the sciencedriven nature of ocean mapping, cultural values are unlikely to inform future regulatory reforms. All this is to illustrate the power that law holds in either endorsing or rejecting ways of relating to the world. This calls for a more critical view of who gets to sit at the table when new laws are being elaborated, as well as who gets to interpret and implement them, and on the basis of what agenda. Of particular significance is the way that law feeds into decision-making processes, with prominent actors wielding the concepts and discourses codified in the law in combination with maps, diagrams and other visual aids to define space and to justify their positioning within it. ${ }^{10}$

The above discussion has sought to demonstrate that there is a disconnect between the foundational narrative of MSP as a neutral tool that helps decision-makers strike a balance between economic, social and environmental imperatives, and the regulatory frameworks that underpin the relevant processes. The sectoral, growth-oriented approach that underlies these frameworks favours, and indeed calls for, the establishment of epistemological and ontological hierarchies that do anything but level the 'tilted plane'. In drawing on such approaches, the laws adopted and implemented produce and prescribe identity signifiers that prevent the interests, perspectives and knowledges of vulnerable groups (i.e. groups that do not belong to any 'priority' maritime sector) from being given due regard within the MSP process. ${ }^{11}$ From a spatial justice perspective, the legal inscription of such hierarchies means that some bodies attract preferential treatment, which obscures the reality that there are many ways of relating to and understanding marine space. Law also produces an atmosphere of exclusivity, in which dominant groups will not only see themselves as justified in contributing to the process, but indeed justified in the rejection of other groups as legitimate stakeholders and knowledge-holders. The following section explores this idea further.

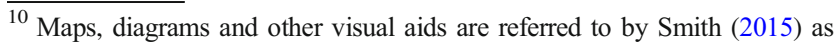
'technologies of power'. The term originates from Foucault (2003).

${ }^{11}$ This links to the broader question of whether a person or group coming to the table is treated as a 'stake-holder', a 'knowledge-holder' or 'rights-bearer', which will have significant implications on one's role and ability to contribute to those processes. Unfortunately, there is not scope for this to be addressed in this piece.
} 


\section{Legal positivism and the neoliberal enclosure of the marine commons through MSP}

This brings us to the second MSP feature that we wish to highlight, namely its role as a vehicle for the realisation of hegemonic territorial discourses. Studies have shown that MSP processes are largely driven by a technocratic, neoliberal logic (Flannery et al. 2018). This is the result of a century's worth of normative discourses grounded in capitalistindustrial framings of the ocean (Steinberg 2001: 149), from the 'gold rush' narrative that shaped the course of the negotiations leading up to the adoption of UNCLOS (Gavouneli 2007: 133), to the present-day mantra of 'Blue Growth'. The portrayal of the marine realm as "a trove of inexhaustible natural resources and mineral riches" and "an area to be conserved for industrial capitalism" is gaining currency as the international community looks to the ocean for solutions to rapidly escalating global challenges (Hannigan 2016: 23). ${ }^{12}$ In response, we are seeing a proliferation of regulatory constellations intended to foster exploitation and growth.

Once again, the EU MSP Directive serves as an example. Being grounded in a 'Blue Growth' discourse, the Directive encourages us to envisage and define marine space from a perspective of economic potential, casting its human and non-human components as either natural resources/ services or actors/sectors forming part of the capitalist system. Perhaps unsurprisingly, the Blue Growth agenda has garnered criticism for allowing economic development and growth to be prioritised at the expense of ecosystem health (Winder and Le Heron 2017), not to mention socio-cultural health tied to the ocean. When marine spaces are viewed from an economic perspective, the lived experiences and social lives they carry within them can be left forgotten, if not ignored. The importance placed on economic development is in line with the European Commission's broader strategy on Blue Growth, ${ }^{13}$ which aims to harness the "untapped' potential of five key economic domains: energy, aquaculture, tourism, biotechnology and marine mineral resources. ${ }^{14}$ With these key economic domains corresponding with key marine sectors, it is not surprising that the practice of MSP has become grounded in a sectoral logic (Jones et al. 2016), which has knock-on effects on the participation of local groups in its decision-making processes (Smith 2015).

Indeed, as is said above, it is not enough to simply permit new actors access to decision-making processes as this tells us little about their ability to 'move' within these spaces (Smith 2015). Approaching the issue from the perspective of spatial justice cuts to the core of that manoeuvrability on behalf of

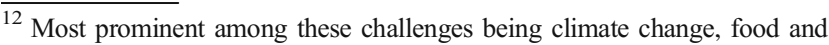
energy insecurity, natural-resource scarcity and the need for improved medical care (OECD 2016).

${ }^{13}$ MSP Directive, preambular paragraph 5.

${ }^{14}$ MSP Directive, article 8.
}

actors. For instance, the sectoral approach adopted under the EU MSP Directive could mean that priority is granted to those representing key maritime sectors. When the idea of participation and the identification of interests and relevant actors are dominated by sectoral-managerial and technocratic language and logic, this risks excluding from decision-making spaces perspectives signified by other aspects linked to social life. A local small-scale fisher is a community-member, perhaps a parent, identifying with a particular class, subscribing to a particular culture or religion and ultimately experiencing the world through a gendered and racial lens. Moreover, they may depend on the ocean for their cultural, spiritual, physical and mental well-being. Yet, it is only their vocation that can secure them a seat at the table and give them a negotiating edge.

This example serves to illustrate how sectoral approaches to MSP, grounded as they are in capitalist-industrial visions of ocean space, tend to make invisible alternative models of maritime development and human-ocean relations (see, for instance, Smith 2015). Specifically, sectorially focused, growth-oriented MSP processes risk forgetting - or, worse, wilfully ignoring - that planning can also serve as an opportunity to develop a socially negotiated, non-economic understanding of oceanic relations, which takes into account the importance of local subsistence and health (physical, mental, spiritual and cultural), as well as local reliance upon the health and resilience of the natural environment. If law is to promote such a view of MSP, it must remain attentive to social concerns regarding the ocean. This entails going beyond the current preoccupation with enabling economic development and towards a clear recognition of the diversity of values associated with socio-natural well-being as this relates to the ocean (Lavau 2013).

This holds important implications for how participation is understood and operationalised. As discussed earlier, legal geography invites us to examine the narratives inscribed in the regulatory framework that underpins each MSP process, these being key determinants of what constitutes a legitimate and legally significant human-ocean relationship within the relevant context. It is these very narratives, and the imaginaries, values and principles they are predicated upon, that incite the endorsement or the rejection of people's existence within ocean spaces, as well as within the spaces of decisionmaking in which planning processes unfold. ${ }^{15}$ Specifically, under the Blue Growth priorities, scales will be tipped in favour of industries targeted by these policies, with local groups being treated as passive beneficiaries in subsequent developments. For decision-making spaces to be open, and for the 'tilted plane' between bodies to be 'levelled', law must play a part in reconceiving and reconfiguring the deliberative processes involved in ocean governance. This entails the

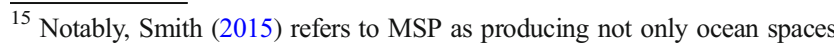
but also the spaces of decision-making within the MSP process.
} 
enactment of normative, regulatory and institutional adjustments and innovations that do not only provide for, but actively facilitate and support the participation of local actors. A renewed engagement with the imaginaries, values and principles underpinning MSP law and practice from the earliest stages of the planning process would help counter the power imbalances that currently undermine engagement across groups and interests (Gopnik et al. 2012; Flannery et al. 2018). ${ }^{16}$ In turn, this would allow for a reshuffling of decision-making spaces so as to accommodate a reappraisal of, for instance, the relevance of ocean governance in protecting rights linked to food, health and culture (see, for instance, Barnes 2018), incorporating also concerns of future generations (Knox 2018), thus painting a more promising picture of MSP as a tool for advancing socio-natural well-being.

Beyond the identification and involvement of local actors within MSP processes, the 'Blue Growth' discourse rooted in MSP processes also illustrates the ways in which technoscientific and legal positivism operate in synergy. This is particularly evident in the interplay between science, technology and property rights. Defined as "[sets] of social relations, mutually recognised claims and decision-making powers over resources" (Beitl 2012: 95), property rights provide an additional entry point for discussing how law may erect borders as a way of "(dis)investing" in particular populations over others (Jeffrey and Vasudevan 2012: 1252). Contrary to traditional maritime activities, such as fishing and navigation, the ocean uses made possible by recent technological advances, among them marine renewable energy, aquaculture and seabed mining, require the permanent occupation of marine space. In legal terms, this translates into the need to grant new rights of access and use. For its part, UNCLOS facilitates the propertisation and privatisation of marine space by subjecting a large part of the ocean to coastal state jurisdiction, thus enabling states to grant rights to non-state actors (Kerr et al. 2015: 109). At the same time, technologies for surveying and monitoring the marine environment allow for easier demarcation and more effective protection of claims over resources (Kerr et al. 2014). This illustrates the emerging ways in which marine space is becoming subject to public and private control through normative, regulatory and institutional enclosure.

Several commentators have discussed the tension between this trend and the nature of the ocean as a commons (see, indicatively, Mansfield 2004). From a legal perspective, the commons are spaces and 'things' that do not fall under the exclusive control of any particular person; that is, they are jointly 'owned' by all (Bosselmann 2015). In this context, the term 'ownership' should not be understood as being synonymous with 'property', the latter denoting that something

\footnotetext{
${ }^{16}$ Smith and Jentoft (2017) call the stages at which these are determined the "meta-order", while Flannery et al. (2018) refer to this as the normative stage of decision-making.
}

can be sold and commercialised at will (Siefkes 2008). Rather, ownership is closer in meaning to 'possession', which signifies that something can be accessed and used. There are, however, instances where the marine commons have become subject to common property regimes, in which resource rights are held by an identifiable group in a system of collective ownership (Satria et al. 2006: 228). Here, rules of access, withdrawal, management and exclusion are elaborated through "self-organized collective-choice arrangements", providing an opportunity for these to be more closely aligned to the socio-economic and environmental particularities of that space (Schlager and Ostrom 1992: 255).

The discussion on common property regimes and their rootedness in customary laws and practices is an important step towards capturing the nuances of the debate on property rights within MSP. These approaches bring into question the suitability of a positivist legal approach which paints property as something that a legal person can manage and exploit for economic purposes. For instance, commentators have pointed out the ill-fit between such an understanding of property and other worldviews not embodying Euro-centric and capitalist models of space, demonstrating the ways that complex histories and epistemologies embedded within these cultures shape people, their lives and spatial surroundings into an inextricable whole (Kerr et al. 2015). In such cases, the relationships that have emerged through strong cultural and social histories may be "more powerful than conventional legal rights" (Kerr et al. 2015: 114). This also relates to the debates surrounding the inability of private rights, grounded in Euro-centric liberal traditions, to recognise and incorporate rights held in common by communities. It also highlights significant tensions within international human rights law, for instance between individual political, social and economic rights and the rights of indigenous peoples under the UN Declaration on the Rights of Indigenous Peoples (Hendry et al. 2018).

On a symbolic level, it is worth noting that, prior to the current era of ocean industrialisation and its corollary of maritime zonation, the ocean was construed in terms of 'freedoms' and 'open access' resources. This gave rise to heterogeneous ocean demoi with diverse 'stakes' and bases for attachment to marine space. This plurality is not always reflected in legal regimes, nor in the technoscientific tools relied on for their implementation. This is particularly evident in the discourse that is emerging around the cadastralisation (the activity of 'comprehensively' recording legal property/spatial ownership) of marine space. Marine cadastres are widely portrayed as a means of instilling legal clarity, certainty and predictability into the MSP process, thus enhancing its transparency and effectiveness (Pinkerton and Silver 2011; Michalak 2018). However, unless they embrace a non-positivist 
conception of normative relations between peoples and the ocean, they will become one of the clearest examples of how, in affirming 'legally recognised' rights over marine space, technological tools may support positivist legal initiatives that lead to the enclosure of marine space and resources.

As a final note, it bears highlighting the need for lawmakers, legal practitioners and academics to continue their efforts to develop a more nuanced understanding of enclosure as it pertains to marine space. Bennett et al. (2015: 62) have made a valuable contribution in this regard, suggesting that 'ocean grabbing' be widely interpreted as the 'dispossession of appropriation of use, control or access to ocean space or resources from prior resource users, rights holders or inhabitants'. Thus defined, ocean grabbing can be said to occur not only when a property right of some sort has been encroached upon, but whenever socio-ecological well-being is undermined as a result of inappropriate governance processes. 'Appropriation' thus becomes disentangled from 'expropriation', welcoming under its conceptual ambit a wider range of phenomena. One example is pollution, which leads to a de facto enclosure of marine space by limiting access to or use of the affected area. Interestingly, what is being 'appropriated' here is the very capacity of the marine environment to absorb disturbances.

Another element falling within this broader notion of 'appropriation' is the use of indigenous, traditional and local knowledges that communities have developed through time with regard to the ocean, its structures, functions, processes and inhabitants. This paper has consistently argued that these must be recognised as valuable sources of knowledge in their own right, alongside other sets of knowledges and information that are of relevance to MSP. They must also be incorporated into planning processes in ways that fully respect their ontological and epistemological underpinnings. Crucially, for this incorporation not to constitute appropriation, information cannot simply be 'extracted' from indigenous, traditional and local knowledge systems and 'transplanted' into decisionmaking. Rather, knowledge-holders themselves must be integrated into the planning process, and their worldviews recognised and meaningfully engaged with. For its part, law must ensure that the agency of the knowledge-holders is respected, and create enabling conditions for them to occupy a more prominent seat at the negotiating table.

\section{Conclusions}

As noted by Mikalsen and Jentoft (2001: 285), the nature of the ocean as a 'commons' and of marine resources as 'public' is not merely a statement of truth, but "a normative utterance" with ethical and institutional implications, alluding to a life beyond marketisation and commercialisation. This raises a number of compelling questions for the MSP community: by whom, to what end, to whose benefit and in whose interest are the marine commons being spatially managed? What the present study has sought to demonstrate is that critical legal scholarship has a valuable contribution to make in this debate, with law providing an important backdrop for interrogating practices of commoning and enclosure. Indeed, as we approach "a global tipping point, the end of the Wild (Blue) Frontier" (Norse 2010: 181), the neoliberal instrumentalisation of law is becoming increasingly indefensible. Rather than serving as a tool of dispossession, law is being called upon to provide opportunities for redress and communal expression (Jeffrey and Vasudevan 2012: 1254). But if law is to fulfil its potential in this regard, it must contend with the ocean's unruly, relational materiality and the challenges that this raises for positivism in its various manifestations. More specifically, water's dimensionality, fluidity and transience render it ontologically multiplicitous. In turn, ontological multiplicity gives rise to a diverse array of social and epistemic values and, by extension, to legal pluralism, as different actors shape themselves and their surroundings into sociomaterial entities through collective institutions, shared territorial practices and discourses. This points to the need for MSP's normative, regulatory and institutional underpinnings to go beyond their current focus on elaborating, strengthening and enforcing abstract, 'rationally-defined' boundaries, embracing instead the socio-cultural dimension of human-ocean relationships. Legal-geographical research can provide important insights in this regard, allowing us to develop an approach to the elaboration and implementation of MSP laws that is more porous, more grounded in social and ecological relativity and more attentive to the lawpower nexus (Davies 2017b). This will require normative, regulatory and institutional innovations that foster participation and allow opportunities for communal learning and adaptation, thus leading to greater socio-natural well-being.

Acknowledgements The authors would like to thank the editors of the special issue for conceiving this collection of papers and for giving them the opportunity to present their work at the 10th People \& the Sea Conference, held by the Centre for Maritime Research (MARE) at the University of Amsterdam, The Netherlands, in June 2019. The authors would also like to give special thanks to Dr. Saskia Vermeylen (University of Strathclyde), whose insightful feedback and continuous support throughout the drafting of this manuscript has greatly enriched its process and result. Finally, the authors would like to thank the two anonymous reviewers for their helpful suggestions.

\section{Compliance with ethical standards}

Conflict of interest The authors declare that they have no conflict of interest. 
Open Access This article is licensed under a Creative Commons Attribution 4.0 International License, which permits use, sharing, adaptation, distribution and reproduction in any medium or format, as long as you give appropriate credit to the original author(s) and the source, provide a link to the Creative Commons licence, and indicate if changes were made. The images or other third party material in this article are included in the article's Creative Commons licence, unless indicated otherwise in a credit line to the material. If material is not included in the article's Creative Commons licence and your intended use is not permitted by statutory regulation or exceeds the permitted use, you will need to obtain permission directly from the copyright holder. To view a copy of this licence, visit http://creativecommons.org/licenses/by/4.0/.

\section{References}

Adger, Neil W., Tor A. Banjaminsen, Katrina Brown, and Hanne Svarstad. 2002. Advancing a political ecology of global environmental discourses. Development and Change 32 (4): 681-715.

Agardy, Tundi, Giuseppe Notarbartolo di Sciara, and Patrick Christie. 2011. Mind the gap: Addressing the shortcomings of marine protected areas through large scale marine spatial planning. Marine Policy 35 (2): 226-232.

Agrawal, Arun. 2003. Sustainable governance of common-pool resources: Context, methods, and politics. Annual Review of Anthropology 32: 243-262.

Anderson, Jon, and Kimberley Peters. 2014. Water worlds: Human geographies of the ocean. Abington: Routledge.

Armitage, Derek R., Ryan Plummer, Fikret Berkes, Robert I. Arthur, Anthony T. Charles, Iain J. Davidson-Hunt, Alan P. Diduck, Nancy C. Doubleday, Derek S. Johnson, Melissa Marschke, Patrick McConney, Evelyn W. Pinkerton, and Eva K. Wollenberg. 2009. Adaptive co-management for social-ecological complexity. Frontiers in Ecology and the Environment 7 (2): 95-102.

Banner, Stuart. 2005. Why Terra nullius? Anthropology and property law in early Australia. Law and History Review 23 (1): 95-131.

Barnes, Richard. 2018. Environmental rights in marine spaces. In Environmental rights in Europe and beyond, ed. Sanja Bogojević and Rosemary Rayfuse, 49-84. Portland: Hart Publishing.

Barry, Andrew, and Evelina Gambino. 2019. Pipeline geopolitics: Subaquatic materials and the tactical point. Geopolitics, forthcoming.

Bear, Christopher. 2012. Assembling the sea: Materiality, movement and regulatory practices in the Cardigan Bay scallop fishery. Cultural Geographies 20 (1): 21-41.

Beitl, Christine M. 2012. Shifting policies, access, and the tragedy of enclosures in Ecuadorian mangrove fisheries: Towards a political ecology of the commons. Journal of Political Ecology 19 (1): 94-113.

Bennett, Luke, and Antonia Layard. 2015. Legal geography: Becoming spatial detectives. Geography Compass 9 (7): 406-422.

Bennett, Nathan James, Hugh Govan, and Terre Satterfield. 2015. Ocean grabbing. Marine Policy 57: 61-68.

Berkes, Fikret. 2012. Implementing ecosystem-based management: Evolution or revolution? Fish and Fisheries 13 (4): 465-476.

Berkes, Fikret, Johan Colding, and Carl Folke. 2002. Introduction. In Navigating social-ecological systems: Building resilience for complexity and change, ed. Fikret Berkes, Johan Colding, and Carl Folke, 1-30. Cambridge: Cambridge University Press.

Blomley, Nicholas, David Delaney, and Richard T. Ford. 2001. Preface: Where is law? In The legal geographies reader: Law, power and space, ed. Nicholas Blomley, David Delaney, and Richard T. Ford, xiii-xxii. Oxford; Malden: Blackwell Publishers.
Borja, Angel, Michael Elliott, Jesper H. Anderson, Torsten Berg, Jacob Cartensen, Benjamin S. Halpern, Anna-Stiina Heiskanen Samuli Korpinen, Julia S. Stewart, George Martin Lowndes, and Naiara Rodriguez-Ezpeleta. 2016. Overview of integrative assessment of marine ecosystems: The ecosystem approach in practice. Frontiers in Marine Science 3 (20).

Bosselmann, Klaus. 2015. Earth governance: Trusteeship of the global commons. Cheltenham: Edward Elgar Publishing.

Boucquey, Noëlle, Luke Fairbanks, Kevin St. Martin, Lisa M. Campbell, and Bonnie McCay. 2016. The ontological politics of marine spatial planning: Assembling the ocean and shaping the capacities of 'community' and 'environment'. Geoforum 75: 1-11.

Boucquey, Noëlle, Kevin St. Martin, Luke Fairbanks, Lisa M. Campbell, and Sarah Wise. 2019. Ocean data portals: Performing a new infrastructure for ocean governance. Environment and Planning D: Society and Space, forthcoming.

Campton, Jeremy W. 2009. Cartography: Performative, participatory, political. Progress in Human Geography 33 (6): 840-848.

Castree, Noel, and Thomas MacMillan. 2001. Dissolving dualisms: Actor-networks and the reimagination of nature. In Social nature: Theory, practice and politics, ed. Noel Castree and Bruce Braun, 208-224. Malden: Blackwell Publishers.

Davies, Margaret. 1996. Delimiting the law: 'Postmodernism' and the politics of law. London: Pluto Press.

Davies, Margaret. 2017a. Asking the law question: The dissolution of legal theory. 4th ed. Sydney: Thomas Reuters Australia Limited \& LawBooks Co..

Davies, Margaret. 2017b. Law unlimited: Materialism, pluralism, and legal theory. Abingdon; New York: Routledge.

Delaney, David. 2003a. Beyond the word: Law as a thing of this world. In Law and geography: Current legal issues, ed. Jane Holder and Carolyn Harrison. Oxford: Oxford University Press.

Delaney, David. 2003b. Law and nature. Cambridge: Cambridge University Press.

Delaney, David. 2010. The spatial, the legal and the pragmatics of worldmaking: Nomospheric investigations. Abingdon; New York: Routledge.

Duck, Robert W. 2012. Marine spatial planning: Managing a dynamic environment. Journal of Environmental Policy \& Planning 14 (1): 67-79.

Ehler, Charles, and Fanny Douvere. 2009. Marine spatial planning: A step-by-step approach toward ecosystem-based management. Paris: IOC-UNESCO.

Fairbanks, Luke, Lisa M. Campbell, Noëlle Boucquey, and Kevin St. Martin. 2018. Assembling enclosure: Reading marine spatial planning for alternatives. Annals of the American Association of Geographers 108 (1): 144-161.

Flannery, Wesley, and Geraint Ellis. 2016. Exploring the winners and losers of marine environmental governance. Planning Theory and Practice 17 (1): 121-151.

Flannery, Wesley, and Micheál Ó Cinnéide. 2012a. A roadmap for marine spatial planning: A critical examination of the European Commission's guiding principles based on their application in the Clyde MSP Pilot Project. Marine Policy 36 (1): 265-271.

Flannery, Wesley, and Micheál Ó Cinnéide. 2012b. Deriving lessons relating to marine spatial planning from Canada's Eastern Scotian Shelf Integrated Management Initiative. Journal of Environmental Policy \& Planning 14 (1): 97-117.

Flannery, Wesley, and Micheál Ó Cinnéide. 2012c. Stakeholder participation in marine spatial planning: Lessons from the Channel Islands National Marine Sanctuary. Society \& Natural Resources 25 (8): $727-742$.

Flannery, Wesley, Noel Healy, and Marcos Luna. 2018. Exclusion and non-participation in marine spatial planning. Marine Policy 88: $32-40$. 
Flannery, Wesley, Jane Clarke, and Benedict McAteer. 2019. Politics and power in marine spatial planning. In Marine spatial planning: Past, present, future, ed. Jacek Zaucha and Kira Gee, 201-217. Palgrave Macmillan.

Foucault, Michel. 2003. 'Society must be defended': Lectures at the college de France, 1975-1976. New York: Picador.

Gavouneli, Maria. 2007. Functional jurisdiction in the law of the sea. Leiden: Martinus Nijhoff Publishers.

Gilbert, Alison J., Karen Alexander, Rafael Sardá, Raminta Brazinskaite, Christian Fischer, Kira Gee, Mark Jessopp, Peter Kershaw, Hans J. Los, David March Morla, Cathal O’Mahony, Mia Pihlajamäki, Siân Rees, and Riku Varjopuro. 2015. Marine spatial planning and good environmental status: A perspective on spatial and temporal dimensions. Ecology and Society 20 (1): 64.

Giordano, Mark. 2003. The geography of the commons: The role of scale and space. Annals of the American Association of Geographers 93 (2): $365-375$

Gopnik, Morgan, Clare Fieseler, Laura Cantral, Kate McClellan, Linwood Pendleton, and Larry Crowder. 2012. Coming to the table: Early stakeholder engagement in marine spatial planning. Marine Policy 36: 1139-1149.

Gray, Tim, and Jenny Hatchard. 2008. A complicated relationship: Stakeholder participation and the ecosystem-based approach to fisheries management. Marine Policy 32 (2): 158-168.

Hannigan, John A. 2016. The geopolitics of deep oceans. Cambridge; Maldern: Polity Press.

Hardt, Michael, and Antonio Negri. 2005. Multitude: War and democracy in the age of empire. London: Penguin Books.

Hardt, Michael, and Antonio Negri. 2009. Commonwealth. Cambridge: Harvard University Press.

Hendry, Jennifer, Melissa L. Tatum, Miriam Jorgensen, and Deirdre Howard-Wagner, eds. 2018. Indigenous justice: New tools, approaches, and spaces. London: Palgrave MacMillan.

Holder, Jane, and Carolyn Harrison. 2003. Connecting law and geography. In Law and geography, ed. Jane Holder and Carolyn Harrison, 3-16. Oxford: Oxford University Press.

Jay, Stephen. 2012. Marine space: Manoeuvring towards a relational understanding. Journal of Environmental Policy \& Planning 14 (1): 81-96.

Jay, Stephen. 2018. The shifting sea: From soft space to lively space. Journal of Environmental Policy \& Planning 20 (4): 450-467.

Jeffrey, Alex, Colin McFarlane, and Alex Vasudevan. 2012. Rethinking enclosure: Space, subjectivity and the commons. Antipode 44 (4): $1247-1267$.

Jones, Martin. 2009. Phase space: Geography, relational thinking, and beyond. Progress in Human Geography 33 (4): 487-506.

Jones, Peter J.S., Louise M. Lieberknecht, and Wanfei Qiu. 2016. Marine spatial planning in reality: Introduction to case studies and discussion of findings. Marine Policy 71: 256-264.

Kerr, Sandy, Kate Johnson, and Jonathan C. Side. 2014. Planning at the edge: Integrating across the land sea divide. Marine Policy 47: 118-125.

Kerr, Sandy, John Colton, Kate Johnson, and Glen Wright. 2015. Rights and ownership in sea country: Implications of marine renewable energy for indigenous and local communities. Marine Policy 58: $108-115$

Kidd, Sue, and David Shaw. 2013. Reconceptualising territoriality and spatial planning: Insights from the sea. Planning Theory \& Practice 14 (2): 180-197.

Knol, Maaike. 2013. Making ecosystem-based management operational: Integrating monitoring in Norway. Maritime Studies 12 (5): 1-17.

Knox, John. 2018. Report of the special rapporteur on the issue of human rights obligations relating to the enjoyment of a safe, clean, healthy and sustainable environment. Human Rights Council Doc. A/HRC/37/59.
Kobryn, Halina T., Greg Brown, Jennifer Munro, and Susan A. Moore. 2018. Cultural ecosystem values of the Kimberley coastline: An empirical analysis with implications for coastal and marine policy. Ocean \& Coastal Management 162: 71-84.

Kraan, Marloes, Astrid Hendriksen, Luc van Hoof, Judith van Leeuwen, and Charlène Jouanneau. 2014. How to dance? The tango of stakeholder involvement in marine governance research. Marine Policy 50 (B): 347-352.

Lavau, Stephanie. 2013. Going with the flow: Sustainable water management as ontological cleaving. Environment and Planning D: Society and Space 31 (3): 416-433.

Lefebvre, Henri. 1991. The production of space. Oxford: Blackwell Publishers.

Maguire, Bernadine, Jonathan Potts, and Stephen Fletcher. 2012. The role of stakeholders in the marine planning process: Stakeholder analysis within the Solent, United Kingdom. Marine Policy 36 (1): 246-257.

Mancisidor, Mikel. 2015. Is there such a thing as a human right to science in international law? European Society of International Law Reflections 4 (1).

Mansfield, Becky. 2004. Neoliberalism in the oceans: "Rationalization," property rights, and the commons question. Geoforum 35 (3): 313-326.

Massey, Doreen. 2005. For space. London: Sage.

McConville, Mike, and Wing Hong Chui, eds. 2007. Research methods for law. Edinburgh: Ednburgh Univeristy Press.

Michalak, Séverine. 2018. A multipurpose marine cadastre to manage conflict use with marine renewable energy. In Trends and challenges in maritime energy management, ed. Aykut I. Ölçer, Momoko Kitada, Dimitrios Dalaklis, and Fabio Ballini, 447462. Springer 2018.

Mikalsen, Knut H., and Svein Jentoft. 2001. From user-groups to stakeholders? The public interest in fisheries management. Marine Policy 25 (4): 281-292.

Miller, Robert J. 2011. International law of colonialism: A comparative analysis. Lewis \& Clark Law Review 15: 847-922.

Moss, Timothy. 2014. Spatiality of the commons. International Journal of the Commons 8 (2): 457-471.

Murray, Grant, Teresa Johnson, Bonnie J. McCay, Mike Danko, Kevin St. Martin, and Satsuki Takahashi. 2010. Creeping enclosure, cumulative effects and the marine commons of New Jersey. International Journal of the Commons 4 (1): 367-389.

Norse, Elliott A. 2010. Ecosystem-based spatial planning and management of marine fisheries: Why and how? Bulletin of Marine Science 86 (2): 179-195.

OECD. 2016. The ocean economy in 2030. Paris: OECD.

Olson, Julia. 2010. Seeding nature, ceding culture: Redefining the boundaries of the marine commons through spatial management and GIS. Geoforum 41 (2): 293-303.

Philippopoulos-Mihalopoulos, Andreas. 2015. Spatial justice: Body lawscape, atmosphere. Abington; New York: Routledge.

Pierce, Joseph, Deborah Martin, and James T. Murphy. 2011. Relational place-making: The networked politics of place. Transactions of the Institute of British Geographers 36: 54-70.

Pinkerton, Evelyn, and Jennifer Silver. 2011. Cadastralizing or coordinating the clam commons: Can competing community and government visions of wild and farmed fisheries be reconciled? Marine Policy 35 (1): 63-72.

Pomeroy, Robert, and Fanny Douvere. 2008. The engagement of stakeholders in the marine spatial planning process. Marine Policy 32 (5): $816-822$.

Ritchie, Heather, and Geraint Ellis. 2010. 'A system that works for the sea'? Exploring stakeholder engagement in marine spatial planning. Journal of Environmental Planning and Management 53 (6): 701-723.

Robbins, Paul. 2003. Fixed cartographies in a portable landscape-The causes and consequences of land cover categorization. In Political 
ecology: An integrative approach to geography and environmentdevelopment studies, ed. Karl S. Zimmerer and Thomas J. Bassett, 181-200. New York; London: Guilford Press.

Ryan, Barry J. 2015. Security spheres: A phenomenology of maritime spatial practices. Security Dialogue 46 (6): 568-584.

Santos, Catarina Fazão, Tiago Domingos, Maria Adelaide Ferreira, Michael Orbach, and Francisco Andrade. 2014. How sustainable is sustainable marine spatial planning? Part I-Linking the concepts. Marine Policy 49: 59-65.

Satria, Arif, Yoshiaki Matsuda, and Masaaki Sano. 2006. Contractual solution to the tragedy of property rights in coastal fisheries. Marine Policy 30 (3): 226-236.

Schlager, Edella, and Elinor Ostrom. 1992. Property-rights regimes and natural resources: A conceptual analysis. Land Economics 68 (3): 249-262.

Sevilla-Buitrago, Alvaro. 2015. Capitalist formations of enclosure: Space and the extinction of the commons. Antipode 47 (4): 999-1020.

Siefkes, Christian. 2008. The commons of the future: Building blocks for a commons-based society. In Genes, bytes and emissions: To whom does the world belong? ed. Silke Helfrich. Berlin: Heinrich Böll Stiftung.

Smith, Glen. 2012. Losing our way with mapping: Thinking critically about marine spatial planning in Scotland. Ocean \& Coastal Management 69: 210-216.

Smith, Glen. 2015. Creating the spaces, filling them up marine spatial planning in the Pentland Firth and Orkney Waters. Ocean \& Coastal Management 116: 132-142.

Smith, Glen. 2018. Good governance and the role of the public in Scotland's marine spatial planning system. Marine Policy 94: 1-9.

Smith, Glen, and Svein Jentoft. 2017. Marine spatial planning in Scotland. Levelling the playing field? Marine Policy 84: 33-41.
St. Martin, Kevin, and Madeleine Hall-Arber. 2008. The missing layer: Geo-technologies, communities, and implications for marine spatial planning. Marine Policy 32 (5): 779-786.

Steinberg, Peter E. 2001. The social construction of the oceans. Cambridge; New York: Cambridge University Press.

Steinberg, Philip, and Kimberley Peters. 2015. Wet ontologies, fluid spaces: Giving depth to volume through oceanic thinking. Environment and Planning D: Society and Space 33 (2): 247-264.

Tafon, Ralph V. 2018. Taking power to sea: Towards a post-structuralist discourse theoretical critique of marine spatial planning. Environment and Planning C: Politics and Space 36 (2): 258-273.

Vermeylen, Saskia. 2013. The Nagoya protocol and customary law: The paradox of narratives in the law. Law, Environment and Development Journal 9 (2): 185-200.

Watson, Irene. 2014. Raw law: Aboriginal peoples, colonialism and international law. Abington; New York: Routledge.

Watts, Christopher. 2014. Relational archaeologies: Humans, animals, things. Abingdon; New York: Routledge.

Whatmore, Sarah. 2003. De/re-territorializing possession: The shifting spaces of property rights. In Law and geography. Jane Holder and Carolyn Harrison. Oxford: Oxford University Press.

Winder, Gordon M., and Richard Le Heron. 2017. Assembling a blue economy moment? Geographic engagement with globalizing biological-economic relations and multi-use marine environments. Dialogues in Human Geography 7 (1): 3-26.

Young, Michaela. 2015. Building the blue economy: The role of marine spatial planning in facilitating offshore renewable energy development. The International Journal of Marine and Coastal Law 30 (1): 148.

Publisher's note Springer Nature remains neutral with regard to jurisdictional claims in published maps and institutional affiliations. 